\title{
Predictors of Bullying and Victimisation in Children with Attention-Deficit/Hyperactivity Disorder
}

ANAMARIJA ŽIC RALIĆ ${ }^{* 1}$, DANIEla CVITKOVIĆ ${ }^{2}$ AND

SNJEŽANA SEKUŠAK-GALEŠEV ${ }^{2}$

$\approx$ The objective of this paper is to determine whether age, gender, Individualised Education Programme, the experience of victimisation by peers, and the experience of bullying others are predictors of bullying and victimisation in children with Attention-Deficit/Hyperactivity Disorder (ADHD). The sample consisted of children aged from 7 to 15 with ADHD diagnosis $(\mathrm{N}=72)$. Gender is a significant predictor of physical bullying, whereas the predictors of verbal bullying are gender, being enrolled in an Individualised Education Programme (IEP), verbal victimisation and the feeling of security. The males with ADHD without any school accommodations (IEP) and who are exposed to verbal victimisation are also more often verbally aggressive towards their peers. Children with ADHD who are verbally aggressive and feel secure in the school setting are more exposed to verbal victimisation.

Keywords: attention-deficit/hyperactivity disorder, bullying, victimisation by peers, predictors, individualised education programme

$1 \quad{ }^{\star}$ Corresponding Author. University of Zagreb, Faculty of Education and Rehabilitation Sciences, Croatia; anamarija.zic.ralic@erf.hr.

2 University of Zagreb, Faculty of Education and Rehabilitation Sciences, Croatia. 


\section{Napovedovalci ustrahovanja in viktimizacije otrok z motnjo pozornosti s hiperaktivnostjo}

Anamarija Žic Ralić, Daniela Cvitković in

SNJEŽANA SEKUŠAK - GALEŠEV

$\approx$ Namen prispevka je ugotoviti, ali so starost, spol, individualiziran program šolanja, izkušnje viktimizacije vrstnikov in izkušnje ustrahovanja drugih napovedovalci ustrahovanja in viktimizacije otrok z motnjo pozornosti s hiperaktivnostjo. Vzorec predstavljajo otroci, stari od sedem do petnajst let, $\mathrm{z}$ diagnozo motnje pozornosti s hiperaktivnostjo $(\mathrm{N}=$ 72). Spol je pomemben napovedovalec fizičnega ustrahovanja, medtem ko so napovedovalci besednega ustrahovanja spol, vključitev v individualiziran program izobraževanja (IPI), besedna viktimizacija in občutek varnosti. Dečki z motnjo pozornosti s hiperaktivnostjo brez prilagoditev šolanja (IPI) in ki so pogosto izpostavljeni besedni vikitimizaciji, so pogosteje besedno nasilni do svojih vrstnikov. Otroci z motnjo pozornosti s hiperaktivnostjo, ki so besedno nasilni in se počutijo varne znotraj šolskega okolja, so bolj izpostavljeni besedni viktimizaciji.

Ključne besede: motnja pozornosti s hiperaktivnostjo, ustrahovanje, vrstniška viktimizacija, napovedovalci, individualiziran program šolanja 


\section{Introduction}

'Bullying' implies aggressive behaviour, in which an individual or a group of individuals repeatedly attacks, humiliates or excludes a relatively powerless peer (Salmivalli, 2010). In this research 'bullying' is used as an umbrella term referring to the overall occurrence including the actions and experiences of both the bully and the victim. The term 'victimisation by peers' refers to the experience of the individual who is targeted by the bullying behaviour whereas 'bullying others' refers to the actions of the perpetrator of the bullying behaviour. The objective of this research is to identify the risk factors that have an impact on victimisation by peers and bullying others in children with attentiondeficit/hyperactivity disorder.

According to the study carried out in Finland by Kumpulainen, Räsänen, and Puura (2001), among the children involved in bullying, attention-deficit/ hyperactivity disorder is the most common psychiatric disorder. Several studies conducted after that one corroborate such results by a finding that children with attention-deficit/hyperactivity disorder are at elevated risk of being involved in bullying either as aggressors or as victims in comparison with typical children (e.g., Bacchini, Affuso, \& Trotta, 2008; Holmberg \& Hjern, 2008; Unnever \& Cornell, 2003; Wiener \& Mak, 2009).

To date, the research into the risk factors for bullying largely concerned typical children. In accordance with the great number of studies that have been carried, using meta-analysis Cook and associates (2010) investigated the predictors of the bully status groups, i.e., bullies, victims and bully-victims. The predictors refer to individual and environmental factors. Some individual predictors have received attention in literature: gender, externalising behaviours, internalising behaviours, self-related cognitions, other-related cognitions, social problem solving, and academic performance (Cook et al., 2010). The socialecological perspective on peer victimisation suggests that both individual and environmental factors influence peer victimisation (Espelage \& Swearer, 2003). The environmental factors that influence bullying include in particular: family and home environment, school climate, community factors, peer status, and peer influence (Cook et al., 2010).

\section{Victimisation by peers}

Although both boys and girls are victimised by peers, they experience different forms of victimisation (i.e., physical, verbal, relational) at different rates (Hanish, 2000). Boys are most likely to be physically victimised, and girls 
are most likely to be relationally victimised (Crick \& Bigbee, 1998). Boys are more often victimised than girls, although this depends somewhat on the form of victimisation (Cook et al., 2010; Swearer, Espelage, Vaillancourt, \& Hymel, 2010). More recent studies bring attention to the fact that bullying may be targeted both within and across gender and may have different meanings when it occurs within versus across gender (for review, see Hanish, Bradshaw, Espelage, Rodkin, Swearer, \& Horne, 2013).

Some children display behaviours whose poses a risk for the occurrence of bullying. One of the reasons that some children become victims of bullying lies in the fact that their peers perceive them to be unable to protect and defend themselves (Fox \& Boulton, 2005; Hodges \& Perry, 1996). Furthermore, low peer acceptance, high peer rejection, and having few or no friends predict increases in victimisation by peers (Card \& Hodges, 2008). Some children develop an easy target status among their peers because they are physically weak, succumb submissively to their peers' demands, or are rejected by their peers and have few friends who would be ready to support and defend them (Card \& Hodges, 2008; Fox \& Boulton, 2005; Hodges \& Perry, 1996). Such children are at elevated risk of bullying as the peers are not humiliated because of bullying, but are rather reinforced by tangible rewards, signs of distress and absence of retaliation (Fox \& Boulton, 2005; Perry, Williard, \& Perry, 1990).

The classical view of the victim of bullying is of a nonaggressive, shy, passive, and submissive child (Olweus, 1998). Studying how the victims behaved in bullying situations, Salmivalli, Karhunen, and Lagerspetz (1996) found that the socalled counter-aggressive victims were not rare. On the contrary, counter-aggressive responses (such as trying to pay back the bully in his own coin, attacking the bully) in bullying situations were rather typical, especially among boy victims. In terms of how such responses influence making the bullying stop or continue, the study by Salmivalli, Karhunen, and Lagerspetz (1996) found that the responses of showing helplessness (e.g., by crying) and counter-aggression in girls, and counter-aggression in boys, have an effect on making the bullying start or continue.

Salmivalli and Nieminen (2002) provided an overview of studies wherein it was identified that victims may also respond with aggression. Moreover, peers find some types of aggressive behaviour extremely irritating. Thus, children who exhibit reactive aggression and show angry retaliatory responses to real or perceived provocations are at especially elevated risk of continued bullying (Camodeca, Terwogt, \& Schuengel, 2002; Hanish 2000). This process is more significant for boys than girls (Hanish, 2000).

To date, the studies make a distinction between nonaggressive (passive) and aggressive (provocative) victims, also called bully-victims (Salmivalli 
\& Peets, 2000; Salmivalli \& Nieminen, 2002). They seem to differ from other victims in several respects: for instance, while internalising problems and psychosomatic problems are typical of victims, bully-victims show high levels of externalising behaviour and hyperactivity (Kumpulainen et al., 1998), and they are particularly at risk of remaining involved in bullying over longer periods of time (Kumpulainen, Räsänen, \& Henttonen, 1999).

Some studies have demonstrated links between involvement in bullying and poor academic performance. While Hanish and Guerra (2002) and Woods and Wolke (2004) failed to demonstrate significant links between peer victimisation and academic achievement, a recent study conducted by Strom, Throesen, Wentzel-Larsen, and Dyb (2013) indicated significant association between bullying and poor academic achievement. Students in schools with higher levels of bullying performed worse academically. Swearer and associates (2010) specified that those students who are harassed and who also have few or no friends and little opportunity for positive peer interactions are at greater risk for low achievement, especially if they already exhibit conduct problems or hyperactivity. Thus, involvement in bullying does not automatically place a child at risk for poor achievement but can be one of a combination of factors that undermine a child's engagement in school, underscoring the need for educators to pay attention to children who are victimised.

Creating a safe environment for children to grow is essential for their maintaining a healthy outlook on their approach to life. From criminal acts to bullying and verbal abuse, school disorder compromises student safety and the learning environment. A study conducted by Eliot, Cornell, Gregory, and Fan (2010) investigated the relationship between student perceptions of support and student willingness to seek help for bullying and threats of violence. The results indicated the relationship between student perceptions of school climate and help-seeking attitudes at both the individual level and at the school level. If students feel safe in talking with teachers and staff about bullying issues they will be more likely to approach staff when a problem arises.

\section{Bullying others}

Children who bully others have little empathy for their victims and have a strong need to dominate and control other people (Olweus, 1998). Findings from recent studies imply that there are subgroups of bullies who differ from each other in significant respects. For a long time, researchers and practitioners regarded bullies as individuals who lack social skills and have low self-esteem, deficiencies in social information processing, low social standing and peer 
group, and other adjustment problems (Salmivalli \& Peets, 2009). Researchers have recently linked bullying behaviour to seemingly positive social competencies, including high social intelligence (Kaukiainen et al., 1999), and being seen by peers as powerful, attractive, popular, and leaders in their schools (Swearer et al., 2010). At least such 'socially smart' bullies do not seem to fit the picture of reactively aggressive children, who interpret the social cues inaccurately, easily lose self-control, suffer from social rejection in the peer group, etc. Although bullies were significantly less aggressive than bully-victims in the study of Salmivalli and Nieminen (2002), they scored higher than victims and controls on both reactive and proactive aggression. However, observations at the person level indicated that bullies were not only overrepresented among children who were both reactively and proactively aggressive but also among the only reactively aggressive as well as the only proactively aggressive groups.

\section{Attention-Deficit /Hyperactivity Disorder (ADHD)}

Characteristics of children with ADHD increase their vulnerability to bullying participation and its behavioural aftermath. Externalising behaviours and other symptoms of ADHD, including poor impulse control and reduced frustration tolerance, have the potential to lead to social difficulties for children with ADHD (Taylor, Saylor, Twyman, \& Macias, 2010). Poor social competence and peer rejection, as frequent problems of children with $\mathrm{ADHD}$, has a special role to play (Barkley, 200o; Hoza, 2007). In the process, the above-mentioned indicates that poor social competence and peer rejection are essential factors for bullying (Cook et al., 2010). In addition, there are difficulties in controlling environmental noise and their own emotions, which interfere with the activity the children with ADHD are involved with (Rief, 1998), difficulties in processing social situations which cause misinterpretation and, consequently, in unclear, provocative situations they attribute malevolence to peers and respond aggressively, and are more likely than peers to believe that aggressive behaviour will lead them to achieve the objective desired (Dumas, 1998).

The results of a considerable number of studies indicate ADHD as a risk factor for bullying (Bacchini et al., 2008; Holmberg \& Hjern, 2008; Unnever \& Cornell, 2003; Wiener \& Mak, 2009). Furthermore, children with ADHD are more likely to engage in bullying, either as being victims or being perpetrators of bullying in comparison with their classmates (Holmberg \& Hjern, 2008; Taylor et al., 2010; Unnever \& Cornell, 2003; Wiener \& Mak, 2009). Results from the study of Taylor and associates (2010) suggest that the psychological impact of peer Victimisation on youth with ADHD who experience bullying-as 
victims, perpetrators, or both-are more likely to show psychosocial problems above and beyond their attention and social competence difficulties.

Unnever and Cornell (2003) believe that students with ADHD are more likely to become involved in bullying due to their poor self-control. The impact of impulsivity was also detected in a large cohort of typical adolescents $(\mathrm{N}=1232)$, wherein it was detected that in both female and male adolescents' impulsivity exacerbates the effects of community violence exposure by increasing involvement in deviant behaviour (Low \& Espelage, 2014). One earlier study of the predictors of bullying by Espelage, Bosworth, and Simon (2001) found a significant association between impulsivity and a behavioural measure of bullying (e.g., name calling, teasing, threatening other students) among a sample of sixth-grade students.

In their study, Holmberg and Hjern (2008) found that the ADHD symptoms were significantly associated with bullying others, but also with victims of bullying. Children with ADHD more often demonstrate aggressive behaviour and have difficulties interpreting social codes, are three times more actively involved in bullying and ten times more likely to be classified as victims of bullying in comparison with children without ADHD (Holmberg \& Hjern, 2008). A similar finding was also obtained in the study by Wiener and Mak (2009), wherein $57.5 \%$ of children with ADHD in the sample experienced some form of bullying (as a victim, bully or both) compared to $13.6 \%$ of children in the comparison group.

When mention is made of a gender difference among children with ADHD concerning bullying, Wiener and Mak (2009) detected that boys with ADHD bullied others more frequently than girls, and girls were more likely to become victims of bullying. However, such findings should be interpreted with caution, along with taking into account that aggressive behaviour is socially less acceptable for girls than for boys.

Timmermanis \& Wiener (2005) investigated social correlates of bullying in adolescents with ADHD. They found that adolescents with ADHD perceived themselves as having lower total, peer, and family social support than adolescents without ADHD did. Among adolescents with ADHD, victimisation by peers was associated with higher levels of parent-rated peer relation problems and lower levels of perceived social support. These social factors were not associated with participation in bullying others among adolescents with ADHD (Timmermanis \& Wiener, 2005).

In accordance with the preceding, the objective of this study is to investigate the impact of gender, age, academic performance, decisions on academic accommodations, that is, IEP (Individual Education Programme), experienced 
victimisation, experienced bullying and the feeling of security on victimisation by peers and bullying others in children with attention-deficit/hyperactivity disorder.

\section{Method}

\section{Participants}

The study sample comprised 72 first-through-eighth graders of $\mathrm{Za}$ greb elementary schools with ADHD diagnoses, 59 of whom were boys and 13 were girls. Elementary school in Croatia has eight grades in total, the first four of which are general education-oriented (lower grades) and the other four are subject-oriented (higher grades). Twenty-eight of 72 participants attended one of the lower elementary school grades, and 44 attended one of the higher grades. The age of students was between 7 and 15, but the average age was 12. To be selected as potential participants in the sample required the students have a confirmed ADHD diagnosis, as validated by their school files. According to the subtypes of ADHD, students were divided into two categories: ADHD Combined and Predominantly Inattentive Type. In total, the sample comprised $75 \%$ of students (54) in the ADHD Combined Type category, and $25 \%$ of students (18) in the category of ADHD Predominantly Inattentive Type.

For the largest percentage (86\%) of students, an Individualised Education Programme (IEP) had been determined, whereas $13.9 \%$ of students had not received any decision on specific accommodations to compensate for individual weaknesses. In addition to ADHD, a majority of students (40) also had additional impairments, whereas 32 of them had no additional impairment at all or had no impairments specified in their school files. Table 1 indicates additional impairments of more than 40 students since a few children had more than one additional impairment. In the entire sample, there were only four boys who were administered the following ADHD-related medications: Lamictal, Normabel, Haldol, and Concerta. The pharmacological treatment of children with ADHD is not widespread in Croatia; it is only used for the most prominent symptoms which lead to frequent conflicts between the child and his/her environment. 
Table 1

Incidence of additional impairments

\begin{tabular}{lc}
\hline Additional impairment & N \\
\hline $\begin{array}{l}\text { Specific learning disability (dyslexia, dysgraphia, dyscalculia, } \\
\text { developmental reading and writing disorders) }\end{array}$ & 32 \\
Speech (pronunciation) and language disorders & 9 \\
Conduct disorders & 5 \\
Emotional impairments & 5 \\
Cerebral palsy & 1 \\
Agenesis of the corpus callosum & 1 \\
Intellectual disability & 1 \\
\hline
\end{tabular}

\section{Instrument}

The study uses the School-Bullying Questionnaire (UŠN, 2003) authored by Buljan Flander, Karlović and Štimac, designed in line with the Olweus Bully/ Victim Questionnaire (Šimić, 2004). The UŠN-2003 included questions about age, gender, feelings of acceptance and security, and ten school bullying-related questions, including Victimisation and Bullying Scales, questions concerning the age and gender of perpetrators of specific forms of bullying, the victimised child's confidant, and the person who tried to help the child after finding out about victimisation (Buljan Flander, Durman Marijanović, \& Ćorić Špoljar, 2007).

The Victimisation and Bullying Scales consist of 11 statements, which concern different forms of school bullying. Each student was to mark the frequency of a specific type of victimisation, i.e., bullying with an ' $\mathrm{X}$ '. In the context of incidence, the student could choose among one of the following answers: Practically every day; Seldom or sometimes; and Never. The results of either scale represented the total of points for all 11 items. Each participant could obtain a minimum of 11 points per scale (if all statements were answered with Never) to a maximum of 33 points (if all statements were answered with Practically every day).

In this study carried out on a sample of 72 students, the Cronbach alpha coefficient for the Victimisation Scale and for the Bullying Scale was $\alpha=.81$ and $\alpha=.82$, respectively.

\section{Procedure}

After the approval obtained from the Ministry of Science, Education and Sports and the Education and Teacher Training Agency, in compliance with 
the Children Research Ethics Code (Ajduković \& Kolesarić, 2003), prior to the implementation of the study, the parents were informed of the research and their consent was requested to allow their children to participate in the study.

In total, the parents received 124 consent forms, 80 of which were duly signed and returned. Finally, 76 questionnaires were filled out, 72 of which were valid.

The data were collected in twelve regular elementary schools in the Zagreb region throughout a period of two months in 2013. Although the questionnaire was initially planned to be filled out by groups, the inquiry was also conducted individually at some places. At the very beginning, the purpose and the objective of the study were explained, and the students were given instructions on how to fill out the questionnaire. Given the primary characteristics of ADHD (attention deficit), some students needed considerably more time than originally planned to fill out the questionnaire, additional explanation for each particular item, and more frequent work-related focusing. The time required to fill out the questionnaire varied depending on the student and his/her abilities. On average, it took about 15 minutes. All students received coloured cards as a working aid (similar to reading cards) to help them follow the items, that is, to mark the answer of their choice.

\section{Results}

Table 2 first indicates the descriptive statistics of the Victimisation and Bullying Scales.

Table 2

Basic descriptive parameters $(N=72)$

\begin{tabular}{|c|c|c|c|c|c|c|c|}
\hline & \multirow[t]{2}{*}{ M } & \multirow{2}{*}{ SD } & \multirow{2}{*}{$\begin{array}{c}\text { Theoretical } \\
\text { range }\end{array}$} & \multirow{2}{*}{$\begin{array}{l}\text { Minimum } \\
\text { value }\end{array}$} & \multirow{2}{*}{$\begin{array}{l}\text { Maximum } \\
\text { value }\end{array}$} & \multicolumn{2}{|c|}{$\begin{array}{c}\text { Kolmogorov-Smirnov } \\
\text { Test }\end{array}$} \\
\hline & & & & & & z & $\mathrm{p}$ \\
\hline Victimisation Scale & 17.63 & 3.81 & $11-33$ & 12 & 33 & 1.45 & $.03^{*}$ \\
\hline Bullying Scale & 15.08 & 3.35 & $11-33$ & 11 & 27 & 1.66 & $.00^{* *}$ \\
\hline Verbal victimisation & 7.78 & 1.79 & $4-12$ & 4 & 12 & 1.31 & .07 \\
\hline Physical victimisation & 4.56 & 1.38 & $3-9$ & 3 & 9 & 2.51 & $.00^{* *}$ \\
\hline Sexual victimisation & 1.12 & .41 & $1-3$ & 1 & 3 & 4.43 & $.00^{* *}$ \\
\hline Economic victimisation & 2.57 & .89 & $2-6$ & 2 & 6 & 2.98 & $.00^{* *}$ \\
\hline Emotional victimisation & 1.61 & .67 & $1-3$ & 1 & 3 & 2.61 & $.00^{* *}$ \\
\hline Verbal bullying & 6.51 & 1.84 & $4-12$ & 4 & 11 & 1.23 & .07 \\
\hline
\end{tabular}




\begin{tabular}{|c|c|c|c|c|c|c|c|}
\hline & \multirow[t]{2}{*}{ M } & \multirow[t]{2}{*}{ SD } & \multirow{2}{*}{$\begin{array}{c}\text { Theoretical } \\
\text { range }\end{array}$} & \multirow{2}{*}{$\begin{array}{l}\text { Minimum } \\
\text { value }\end{array}$} & \multirow{2}{*}{$\begin{array}{l}\text { Maximum } \\
\text { value }\end{array}$} & \multicolumn{2}{|c|}{$\begin{array}{c}\text { Kolmogorov-Smirnov } \\
\text { Test }\end{array}$} \\
\hline & & & & & & z & $p$ \\
\hline Physical bullying & 4.13 & 1.27 & $3-9$ & 3 & 9 & 2.10 & $.00^{* *}$ \\
\hline Sexual bullying & 1.07 & .35 & $1-3$ & 1 & 3 & 4.56 & $.00^{* *}$ \\
\hline Economic bullying & 2.15 & .43 & $2-6$ & 2 & 4 & 4.35 & $.00^{* *}$ \\
\hline Emotional bullying & 1.22 & .45 & $1-3$ & 1 & 3 & 4.08 & $.00^{* *}$ \\
\hline
\end{tabular}

Note. ${ }^{*} \mathrm{p}<.05,{ }^{* *} \mathrm{p}<.01$

Distributions of results of the Victimisation and Bullying Scales and all subscales (with the exception of the verbal victimisation and verbal bullying subscales, which are not statistically significantly different from normal distributions) are positively asymmetrical.

The dependent variables selected for this paper include verbal and physical bullying and verbal and physical victimisation because such forms of bullying, i.e., victimisation, turned out to be the most common for this sample of respondents (see Table 3 ).

Table 3

Incidence and percentage of physical victimisation in a sample of 72 children with $A D H D$

\begin{tabular}{|c|c|c|c|c|c|c|}
\hline \multirow[t]{2}{*}{ Victimisation } & \multicolumn{2}{|c|}{ Never } & \multicolumn{2}{|c|}{$\begin{array}{l}\text { Seldom or } \\
\text { sometimes }\end{array}$} & \multicolumn{2}{|c|}{$\begin{array}{l}\text { Practically } \\
\text { every day }\end{array}$} \\
\hline & $\mathrm{N}$ & $\%$ & $\mathrm{~N}$ & $\%$ & $\mathrm{~N}$ & $\%$ \\
\hline Other students call me mean and hurtful names & 5 & 6.9 & 45 & 62.5 & 22 & 30.6 \\
\hline Other students say mean and hurtful things to me & 9 & 12.5 & 48 & 66.7 & 15 & 20.8 \\
\hline Other students threaten to do something bad to me & 40 & 55.6 & 27 & 37.5 & 5 & 6.9 \\
\hline Other students hit, kick, push or shove me around & 15 & 20.8 & 47 & 65.3 & 10 & 13.9 \\
\hline Other students beat me up & 58 & 80.6 & 9 & 12.5 & 5 & 6.9 \\
\hline Other students lose or destroy my things on purpose & 45 & 62.5 & 23 & 31.9 & 4 & 5.6 \\
\hline Other students try to extort money from me & 65 & 90.3 & 4 & 5.6 & 3 & 4.2 \\
\hline Other students do hurtful things to me & 50 & 69.4 & 18 & 25.0 & 4 & 5.6 \\
\hline Other students exclude me from play/they completely ignore me & 35 & 48.6 & 30 & 41.7 & 7 & 9.7 \\
\hline Other students tell lies or spread false rumours about me & 19 & 26.4 & 38 & 52.8 & 15 & 20.8 \\
\hline Other students touch me on my body in an unpleasant way & 65 & 90.3 & 5 & 6.9 & 2 & 2.8 \\
\hline
\end{tabular}

The results indicate that $10 \%$ of children with ADHD reported that they experienced victimisation practically every day, and $3 \%$ of children with 
ADHD admitted to bullying behaviour practically every day; $5 \%$ of children responded that they never experienced victimisation, and $11 \%$ that they never perpetrated bullying.

Table 3 illustrates that children with ADHD most often experienced some forms of verbal victimisation: other students called them mean and hurtful names, said mean and hurtful things to them and told lies or spread false rumours about them. For forms of physical victimisation, 13.9\% of children reported that they experienced being hit, kicked, pushed or shoved around practically every day, whereas more severe forms of physical victimisation were seldom experienced.

Table 4 shows that children with ADHD reported that they most often perpetrated some forms of verbal bullying: called other students mean and hurtful names, said mean and hurtful things to other students and told lies and spread false rumours about other students, whereas $11.1 \%$ of children reported that they hit, kicked, pushed or shoved other students around practically every day, whereas other forms of physical bullying were rare.

Table 4

Incidence and percentage of bullying in a sample of 72 children with ADHD

\begin{tabular}{|c|c|c|c|c|c|c|}
\hline \multirow{2}{*}{ Bullying } & \multicolumn{2}{|c|}{ Never } & \multicolumn{2}{|c|}{$\begin{array}{l}\text { Seldom or } \\
\text { sometimes }\end{array}$} & \multicolumn{2}{|c|}{$\begin{array}{l}\text { Practically } \\
\text { every day }\end{array}$} \\
\hline & $\mathrm{N}$ & $\%$ & $\mathrm{~N}$ & $\%$ & $\mathrm{~N}$ & $\%$ \\
\hline I call other students mean and hurtful names & 26 & 36.1 & 39 & 54,2 & 7 & 9.7 \\
\hline I say mean and hurtful things to other students & 20 & 27.8 & 40 & 55.6 & 12 & 16.7 \\
\hline I threaten to do something bad to other students & 54 & 75 & 18 & 0 & 0 & 0 \\
\hline I hit, kick, push or shove other students around & 31 & 43.1 & 33 & 45.8 & 8 & 11.1 \\
\hline I beat other students up & 61 & 84.7 & 9 & 12.5 & 2 & 2.8 \\
\hline I lose or destroy other students' things & 64 & 88.9 & 7 & 9.7 & 1 & 1.4 \\
\hline I extort money from other students & 70 & 97.2 & 2 & 2.8 & 0 & 0 \\
\hline I do hurtful things to other students & 54 & 75 & 17 & 23.6 & 1 & 1.4 \\
\hline I exclude other students from play/completely ignore other students & 57 & 79.2 & 14 & 19.4 & 1 & 1.4 \\
\hline I tell lies or spread false rumours about other students & 32 & 44.4 & 34 & 47.2 & 6 & 8.3 \\
\hline I touch other students on their body in an unpleasant way & 69 & 95.8 & 1 & 1.4 & 2 & 2.8 \\
\hline
\end{tabular}

To detect significant predictors of bullying, a multivariate regression analysis was carried out, which included a selection of seven potential predictors: Age, Gender, Academic performance, Individual Education Programme (IEP), Verbal victimisation, Physical victimisation and Security. Multivariate 
regression analyses to reveal significant predictors of victimisation included a selection of seven potential predictors: Age, Gender, Academic performance, IEP, Verbal bullying, Physical bullying and Security. Statistics regarding age, academic performance and IEP (whether the student is in possession of one or not) were obtained from the general part of the survey. The statistics concerning security were formulated as a simple linear combination of items that described the feeling of security in different places regarding the school environment: in the classroom, on the playground, in the dining hall, in the washrooms, in the school corridor, in the school gymnasium. The students' evaluation of the feeling of security included the following responses: Insecure, Neither, Secure; the higher the score, the stronger the feeling of security.

Acceptance by peers was not selected as a potential predictor variable since most children felt accepted, that is, there were only five children who reported being rejected by peers (see Table 5).

Table 5

Incidence and percentage of responses for the school peer acceptance variable in a sample of 72 children with $A D H D$

\begin{tabular}{lcc}
\hline Valid & N & $\%$ \\
\hline Accepted & 51 & 70.8 \\
Rejected & 5 & 6.9 \\
Neither & 8 & 11.1 \\
I don't know & 8 & 11.1 \\
\hline Total & 72 & 100.0 \\
\hline
\end{tabular}

Table 6

Determinants of verbal bullying

\begin{tabular}{lccc}
\hline Variable & B & SE B & $\beta$ \\
\hline Gender & -1.36 & .53 & $-.29^{*}$ \\
Age & .09 & .10 & .10 \\
Academic performance & -.03 & .19 & -.02 \\
IEP & -1.26 & .41 & $-.35^{* *}$ \\
Verbal victimisation & .32 & .13 & $.31^{*}$ \\
Physical victimisation & -.19 & .18 & -.15 \\
Security & .14 & .07 & $.25^{*}$ \\
\hline
\end{tabular}

Note. $\mathrm{N}=72, \mathrm{~B}=$ Unstandardized Coefficients, SE B = Standard Errors of B, $\beta=$ Standardised Coefficients (Beta). ${ }^{*}\left(\mathrm{R}^{2}=.31\right) .{ }^{*} \mathrm{p}<.05,{ }^{* *} \mathrm{p}<.01$. 
Table 6 indicates the relationship between seven potential predictors and the response variable of verbal bullying. The variables were scaled so as to be able to see how gender, IEP, verbal victimisation and the feeling of security in school were statistically significant predictors of verbal bullying.

The boys were more often verbally aggressive than girls were. The children without any IEP more commonly perpetrated verbal bullying as well as those children who were more often victims of verbal bullying. It is interesting to note that children who felt secure in school were more commonly perpetrators of verbal bullying.

The preceding variables accounted for $31 \%$ of the variance of the Scale of Verbal Bullying.

Table 7

Determinants of physical bullying

\begin{tabular}{lccc}
\hline Variable & B & SE B & $\beta$ \\
\hline Gender & -1.11 & .39 & $-.34^{* *}$ \\
Age & .02 & .08 & .04 \\
Academic performance & -.09 & .14 & -.08 \\
IEP & -.47 & .30 & -.19 \\
Verbal victimisation & .07 & .10 & .09 \\
Physical victimisation & .02 & .14 & .02 \\
Security & .06 & .05 & .14 \\
\hline
\end{tabular}

Note. $\mathrm{N}=72, \mathrm{~B}=$ Unstandardized Coefficients, $\mathrm{SE} \mathrm{B}=$ Standard Errors of $\mathrm{B}, \beta=$ Standardised Coefficients (Beta). $R^{2}=.20^{* *}$.

Table 7 indicates the results of the regression analysis with identical predictors and the Scale of Physical Bullying as a dependent variable. Gender was the only statistically significant predictor of physical bullying and accounted for $20 \%$ of the variance of physical bullying. Boys were more commonly physically aggressive, whereas other variables did not predict physical bullying.

To obtain a significant regression coefficient, the variables of academic performance and IEP were excluded from the analysis when verbal victimisation was a response variable. In case of verbal victimisation as a response variable, security and verbal bullying were statistically significant predictors and accounted for $15 \%$ of variance of the Scale of Verbal Victimisation (see Table 8). The children who were more often perpetrators of verbal bullying also more commonly experienced verbal victimisation, and interestingly, children who felt more secure, (as in the case of verbal bullying) more often experienced victimisation. 
Table 8

Determinants of verbal victimisation

\begin{tabular}{lccc}
\hline Variable & B & SE B & $\beta$ \\
\hline Gender & -.10 & .57 & -.02 \\
Age & .13 & .11 & .15 \\
Verbal bullying & .34 & .17 & $.36^{*}$ \\
Physical bullying & .20 & .24 & -.14 \\
Security & .19 & .07 & $.34^{* *}$ \\
\hline
\end{tabular}

Note. $\mathrm{N}=73, \mathrm{~B}=$ Unstandardized Coefficients, $\mathrm{SE} \mathrm{B}=$ Standard Errors of $\mathrm{B}, \beta=$ Standardised Coefficients (Beta). $\mathrm{R}^{2}=.15^{* *},{ }^{*} \mathrm{p}<.05,{ }^{* *} \mathrm{p}<.01$.

Table 9

Determinants of the Scale of Physical Victimisation

\begin{tabular}{lccc}
\hline Variable & B & SE B & $\beta$ \\
\hline Gender & -1.03 & .42 & $-.29^{*}$ \\
Age & .02 & .08 & .04 \\
Academic performance & -.09 & .14 & -.08 \\
IEP & .08 & .33 & -.03 \\
Verbal bullying & -.00 & .13 & -.02 \\
Physical bullying & .08 & .18 & .07 \\
Security & -.13 & .05 & $-.30^{*}$ \\
\hline
\end{tabular}

Note. $\mathrm{N}=72, \mathrm{~B}=$ Unstandardized Coefficients, $\mathrm{SE} \mathrm{B}=$ Standard Errors of $\mathrm{B}, \beta=$ Standardised Coefficients (Beta). ${ }^{*}{ }^{2}=.19,{ }^{*} p<.05,{ }^{* *} p<.01$.

Table 9 shows the results of the regression analysis when the Scale of Physical Victimisation is used as a response variable. Security and gender were significant predictors of physical victimisation and accounted for $19 \%$ of the variance of the Scale of Physical Victimisation. The children who felt more insecure were more often victims of physical bullying. Boys were also more often victims of physical bullying, just as they were more commonly perpetrators of verbal and physical bullying. 


\section{Discussion}

The objective of this research is to determine the impact of age, gender, academic performance, IEP, the experience of victimisation by peers, the experience of bullying others and security, on bullying and victimisation in children with attention-deficit/hyperactivity disorder. The data were obtained based on the self-evaluation of elementary school children with ADHD diagnosis $(\mathrm{N}=72)$, and they indicate the children's experience of victimisation by peers, that is, of bullying others.

\section{Incidence of Peer Victimisation and Bullying}

The children's self-estimations show that they more often felt themselves to be victims of bullying than they considered themselves as perpetrators. Most commonly, they were victims of verbal bullying and milder forms of physical bullying. Such results can be corroborated by many studies. As mentioned above, children with ADHD frequently suffer from poor peer status, which automatically enhances their probability of being bullied (Wan Salwina, Nik Ruzyanei, Tuti Iryani, Shamsul, Aniza, \& Zasmani, 2010). Other children might find the ADHD symptoms weird, which can also make the children with ADHD targets of bullies (Wan Salwina et al., 2010). In addition, the learning problems and discipline difficulties in school, experienced by many ADHD children, might identify them as objects of scorn or derision by their peers (Unnever \& Cornell, 2003). Provocative or inappropriate behaviour, which is commonly associated with ADHD, as well as poor social skills, might elicit the scornful behaviour of classmates towards the child with ADHD or their aggressive responses to such children (Unnever \& Cornell, 2003). Furthermore, failures of attention can lead to a general sense of inadequacy at school, and to a consequent loss of self-esteem, which is often predictive of victimisation by peers in children with ADHD (Bacchini et al., 2008). Unnever and Cornell (2003) showed that students with ADHD were at greater risk of becoming victims of bullying. Notably, $34 \%$ of the students reported being bullied at least two or three times a month in comparison with $22 \%$ of the students who were their counterparts (without $\mathrm{ADHD})$. In contrast, $13 \%$ of the students with ADHD reported that they bullied other students at least two or three times a month in contrast with only $8 \%$ of the students from the control group. Unlike their counterparts, it was detected that it is more likely for the students with ADHD to become victims of bullying but also to bully others. In a sample of 104 nine- to fourteen-year-old children, Wiener and Mak (2009) found that children with ADHD were more likely than 
comparison children to report being victimised by peers. Children with ADHD also reported that they were subjected to verbal, physical, and relational victimisation more often than their counterparts without ADHD were.

\section{Predictors of Bullying Others}

Gender is a common predictor of verbal and physical bullying in our sample, and it is the only such common predictor. More significantly than girls, boys perpetrate both verbal and physical bullying. The references indicate some of the ADHD symptoms that might have an impact on becoming a bully: impulsive behaviour, lack of self-control, reduced empathy and aggressive reactions, often owing to the frustrations experienced by children at school (Bacchini et al., 2008). Unnever and Cornell (2003) believe that the students with ADHD are more likely to start bullying others due to low self-control. The impact of self-control on bullying is more significant than any other variable investigated in the preceding study. The results of Rucklidge (2006) also support this finding. His study of gender differences in neuropsychological functioning showed that males with ADHD showed some evidence of more impaired inhibition than females with ADHD.

As detected, males more often have a diagnosis of ADHD Combined and Predominantly Hyperactive-Impulsive Type, whereas females more commonly have a Predominantly Inattentive Type (Barkley, 2000; Taylor et al., 2010). For that reason, females are less impulsive, that is, have fewer problems with selfcontrol and display aggressive behaviours less frequently. Bacchini, Affuso, and Trotta (2008) found that in males ADHD symptoms are a good predictor of bullying, whereas in females they predict victimisation. Furthermore, the ADHDrelated problems are more common in males, which is also the case in our study.

The second possible explanation results from the environmental approach, whereby the conduct is interpreted in its social context. Higher incidence of bullying in males can also be interpreted as a socially acceptable, even expected male behaviour. Consequently, males can more often perpetrate, but also admit to such conduct in their self-estimations. Females are expected to exhibit internalising, less excessive conduct, which might also result in smaller incidence of such conducts but also in less reliable self-estimations (Sciutto, Nolfi, \& Bluhm, 2004).

In terms of physical bullying, of the seven predictors assumed in our research, only gender seemed to be significant.

In addition to gender, in the context of verbal bullying, other significant predictors are as follows: IEP, verbal victimisation and the feeling of security. The 
predictor of IEP can be justified by the fact that it enables students to have education in accordance with their needs and thus students have better academic performance. The students with ADHD but without the IEP are confronted with considerable frustrations due to inadequate school demands and often respond with verbal aggression to poorer academic performance than they would otherwise deserve according to their efforts and knowledge. It is a common fact that the organisational skills problems characteristic of children with ADHD are strongly associated with academic impairment (ability to manage materials and belongings, e.g., transfer of homework assignments to and from school). Because of that and other reasons, children with ADHD typically experience clinically significant impairment in the school setting as evidenced by lower school grades and achievement scores and higher rates of school dropout in comparison to their peers (DuPaul \& Stoner, 2003; Frazier, Youngstrom, Glutting, \& Watkins, 2007; Langberg, Epstein, Becker, Stephen, Girio-Herrera, \& Vaughn, 2012). In Croatian schools, unfortunately, it can still happen that a child with impairments will not receive education in line with mandatory school accommodations contained in the IEP, which depends on several factors. Sometimes the parents do not consent to an individualised approach as they believe none is needed and that it would stigmatise the child. In children with ADHD Predominantly Hyperactive/Impulsive Type and without difficulties concerning the acquisition of school materials, the organisational and self-control issues are assigned to educational factors and the approach to such children is not individualised. For that reason, they are often reprimanded and criticised by teachers and their peer status is poor. They are scorned and ridiculed by other children, i.e., verbally victimised, which in turn results in their inappropriate verbal response, reactive verbal aggression, that is, the development of the bully-victim pattern (Salmivalli \& Nieminen, 2002). Accordingly, our research also found that verbal victimisation was a significant predictor of verbal bullying.

Security in school was a predictor that affected the occurrence of verbal bullying in an unusual way. It was detected that children who felt more secure in school (in our research, they were males) were more inclined to verbal bullying. One possible explanation could be that feeling of security is based on selfperception of child with ADHD as 'stronger' than other children in school, and 'stronger' than adults who are not able to respond adequately to the challenging behaviour of ADHD children. In a school climate where teachers are powerless, uninterested in peer relations, or insufficiently skilled, a child with ADHD could feel secure to be verbally aggressive toward peers without any consequences. This explanation relates to the results of Meehan, Hughes, and Cavell (2003) that students who perceived their teachers as supportive and involved 
are more likely to do well in school and less likely to display behaviour problems such as bullying. Moreover, Wang, Berry, and Swearer (2013) review research on school climate and bullying behaviour and propose that an unhealthy and unsupportive school climate (e.g., negative relationship between teachers and students, positive attitudes towards bullying) provides a social context that allows bullying behaviour to occur. The feeling of security as a predictor of verbal bullying might also be a consequence of an unrealistic evaluation of the feeling of security as children with ADHD often have unrealistic views of their own feelings and those of others, that is, commonly have illusory perception and self-perception (Owens, Goldfine, Evangelista, Hoza, \& Kaiser, 2007).

\section{Predictors of Peer Victimisation}

There are two identified predictors of verbal victimisation: verbal bullying and security. It was found that children with ADHD (irrespective of their gender) were more exposed to verbal bullying if they were also perpetrators, and they felt secure in school. Such bully/victim situation was detected in a number of studies about children with ADHD, due to their often socially incompetent behaviour (Holbmerg \& Hjern, 2008; Wiener \& Mak, 2009). In accordance with the above-mentioned, it was also found in a sample of typical children that risk factors for victimisation by peers include both aggressive behaviour and social withdrawal (Hanish, 200o). For instance, Hodges and his colleagues (Hodges, Boivin, Vitaro, \& Bukowski, 1999; Hodges, Malone, \& Perry, 1997; Hodges \& Perry, 1999) found that externalising behaviours (operationalised as aggressive, argumentative, and disruptive behaviour, dishonesty, and a pushy peer entry style) and internalising behaviours (operationalised as withdrawal, anxiety, and depression, and a hovering peer entry style) predict victimisation, both concurrently and over time. The correlation between aggressive behaviour and victimisation was also found in the research carried out by Salmivalli, Karhunen, and Lagerspetz (1996), who detected that the absence of aggressive response (counter-aggression) and nonchalance (e.g., acting as if they didn't care) in girls and absence of counter-aggression in boys were factors which had an impact on reduction or termination of bullying. The feeling of security in school reported by children in our sample, which is a predictor of both verbal victimisation and verbal bullying, might reflect some of the characteristics of children with ADHD. Impulsivity, lack of interest in others, low frustration tolerance, verbal and physical aggression, defiant behaviour (Barkley, 20oo; Wåhlstedt, Thorell, \& Bohlin, 2008), focus on instant need fulfilment (Taylor et al., 2010), lack of interpersonal empathy, consideration of other 
pupils' needs, emotions and views (Cordier, Bundy, Hocking, \& Einfeld, 2010), distort the child's perception, that is, are responsible for his/her focus on the current situation, poor awareness of the consequences and the events preceding a situation (Barkley, 200o).

As significant predictors of physical victimisation, in our research, the following predictors can be singled out: gender (males more commonly than females reported physical victimisation), and the feeling of insecurity. Such results do not correspond with the findings in references that indicate that ADHD is directly linked with bullying behaviour in males and victimisation in females (Bacchini et al., 2008). The explanation can probably be found in the type of victimisation in females (relational aggression), which was not one of the predictors of physical victimisation in our study. As indicated in the previous analysis, males were largely more aggressive than females, that is, gender was a significant predictor of physical bullying, and it can be assumed that this was a bully-victim pattern and that the males in our research were both victims and perpetrators of bullying.

The predictor of security, that is, insecurity, refers to the impact of a negative experience due to physical harassment, which is much more difficult than verbal bullying; therefore, in this case, it probably has a more negative influence on self-perception, developing fear and increasing awareness of one's own vulnerability and insecurity in the school setting.

In the context of other potential predictors, it can be seen that in our sample age and academic performance did not have a significant impact on either victimisation or bullying. Academic performance probably had an indirect impact via the predictor of being enrolled in an individual educational programme, but age was not found to be significant for the interpretation of victimisation and bullying. It is possible that poor self-control and other characteristics responsible for bullying behaviour in children with ADHD persist from early childhood to adolescence.

It was identified in our sample that the bully/victim pattern was much more present in boys with ADHD than in girls. It was also detected that age and academic performance were not significant predictors of any form of bullying in our sample of respondents.

\section{Constraints of the Research}

Although the research carried out has constraints due to a positive illusory bias present in the self-evaluation of children with ADHD, the results obtained are an important starting point for further research, but also for the 
planning of interventions to prevent the occurrence of bullying and victimisation in children with ADHD. Consequently, the subsequent research should investigate whether there are any differences between the predictors in the context of bullying in the case that bullying is evaluated by teachers and/or parents.

The results should also be considered with caution as it was impossible to include a comparison group in this phase of research and the group of respondents was relatively small. In the next phase, the examination will be expanded to include a considerably larger number of respondents together with the comparison group, and then the impact of other potential variables on bullying by peers in children with ADHD will be verified.

\section{Conclusion}

The self-estimations in children with ADHD in our study indicated that gender and the feeling of security in school predicted bullying and that gender, IEP (i.e., the support the children obtained in school), and bullying were significant predictors of victimisation. The children with ADHD more commonly felt themselves to be victims than they considered themselves to be perpetrators of bullying, and most frequently as victims of verbal bullying and milder forms of physical bullying.

Gender was an important predictor of physical bullying: males were (more significantly than females) perpetrators of physical bullying, whereas both gender and security were significant predictors of verbal bullying. Males were (more significantly than females) perpetrators of verbal bullying, and felt secure in school.

Verbal bullying and security were significant predictors of verbal victimisation. The children with ADHD who were perpetrators of verbal bullying were also more often exposed to that type of bullying, but still felt secure in the school setting.

Gender and security were significant predictors of physical victimisation. Males were more exposed to physical bullying and felt insecure.

It was found that the bully/victim pattern was much more significantly present in males with ADHD than in girls in our sample.

In comparison with the research in a sample of children without any impairments (Swearer, 2011), neither age nor academic performance was found to be a significant predictor of any form of bullying in our sample of respondents.

The results obtained are an important starting point for further research, but also for planning of interventions to prevent the occurrence of bullying and victimisation in children with $\mathrm{ADHD}$. 


\section{References}

Ajduković, M., \& Kolesarić, V. (Eds.) (2003). Etički kodeks istraživanja s djecom [Ethical code of research with children]. Zagreb: Vijeće za djecu Vlade Republike Hrvatske, Državni zavod za zaštitu obitelji, materinstva i mladeži.

Bacchini, D., Affuso, G., \& Trotta, T. (2008). Temperament, ADHD and peer relations among schoolchildren: The mediating role of school bullying. Aggressive Behavior, 34(5), 447-459. doi: 10.1002/ab.20271

Barkley, R. A. (2000). Taking charge of ADHD. New York, NY: The Guilford Press.

Buljan Flander, G., Durman Marijanović, Z., \& Ćorić Špoljar, R. (2007). Bullying in Croatian schools with regard to gender, age and acceptance/rejection in school. Journal for General Social Issues, 16(1-2), $157-174$.

Camodeca, M., Terwogt, M. M., \& Schuengel, C. (2002). Bullying and victimization among school-age children: Stability and links to proactive and reactive aggression. Social Development, 11(3), 332-345.

Card, N. A., \& Hodges, E. V. (2008). Peer victimization among schoolchildren: Correlations, causes, consequences, and considerations in assessment and intervention. School Psychology Quarterly, 23(4), 451-461. doi: 10.1037/aoo12769

Cook, C. R., Williams, K. R., Guerra, N. G., Kim, T. E., \& Sadek, S. (2010). Predictors of bullying and victimization in childhood and adolescence: A meta-analytic investigation. School Psychology Quarterly, 25(2), 65-83.

Cordier, R., Bundy, A., Hocking, C., \& Einfeld, S. (2010). Comparison of the play of children with attention deficit hyperactivity disorder by subtypes. Australian Occupational Therapy Journal, $57(2)$, 137-145. doi: 10.1111/j.1440-1630.2009.00821.X

Crick, N. R., \& Bigbee, M. A. (1998). Relational and overt forms of peer victimization: A multiinformant approach. Journal of Consulting and Clinical Psychology, 66(2), 337-347.

Dumas, M. C. (1998). The risk of social interaction problems among adolescents with ADHD. Education \& Treatment of Children, 21(4), 447-461.

DuPaul, G. J., \& Stoner, G. (2003). ADHD in the schools: Assessment and intervention strategies (2nd ed.). New York, NY: Guilford.

Eliot, M., Cornell, D., Gregory, A., \& Fan X. (2010). Supportive school climate and student willingness to seek help for bullying and threats of violence. Journal of School Psychology, 48(6), 533-553. doi: 10.1016/j.jsp.2010.07.001

Espelage, D. L., Bosworth, K., \& Simon, T. R. (2001). Short-term stability and prospective correlates of bullying in middle-school students: An examination of potential demographic, psychosocial, and environmental influences. Violence and Victims, 16(4), 411-426.

Espelage, D. L., \& Swearer, S. M. (2003). Research on school bullying and victimization: What have we learned and where do we go from here? School Psychology Review, 32(3), 365-383.

Fox, C. L., \& Boulton, M. J. (2005). The social skills problems of victims of bullying: Self, peer and teacher perceptions. British Journal of Educational Psychology, 75(2), 313-328. doi:10.1348/000709905X25517 
Frazier, T. W, Youngstrom, E. A., Glutting, J. J., \& Watkins, M. W. (2007). ADHD and achievement: Meta-analysis of the child, adolescent, and adult literatures and a concomitant study with college students. Journal of Learning Disabilities, 4o(1), 49-65.

Hanish, L. D. (200o). Predictors of peer victimization among urban youth. Social Development, 9(4), 521-543.

Hanish, L. D., Bradshaw, C. P., Espelage, D. L., Rodkin, P. C., Swearer, S. M., \& Horne, A. (2013). Looking toward the future of bullying research: Recommendations for research and funding priorities. Journal of School Violence, 12(3), 283-295.

Hanish, L. D., \& Guerra, N. G. (2002). A longitudinal analysis of patterns of adjustment following peer victimization. Development and Psychopathology, 14(1), 69-89.

Hodges, E. V. E., Boivin, M., Vitaro, F., \& Bukowski, W. M. (1999). The power of friendship: Protection against an escalating cycle of peer victimization. Developmental Psychology, 35(1), 94-101.

Hodges, E. V. E., Malone, M. J., \& Perry, D. G. (1997). Individual risk and social risk as interacting determinants of victimization in the peer group. Developmental Psychology, 33(6), 1032-1039.

Hodges, E. V. E., \& Perry, D. G. (1999). Personal and interpersonal antecedents and consequences of victimization by peers. Journal of Personality and Social Psychology, 76(4), 677-685.

Holmberg, K., \& Hjern, A. (2008). Bullying and attention-deficit-hyperactivity disorder in 10-yearolds in a Swedish community. Developmental Medicine \& Child Neurology, 5o(2), 134-138. doi: 10.1111/j.1469-8749.2007.02019.x

Hoza, B. (2007). Peer Functioning in Children With ADHD. Journal of Paediatric Psychology, 32(6), 655-663. doi: 10.1093/jpepsy/jsmo24

Kaukiainen, A., Bjorkqvist, K., Lagerspetz, K., Osterman, K., Salmivalli, C., Rothberg, S., et al. (1999). The relationships between social intelligence, empathy, and three types of aggression. Aggressive Behavior, 25(2), 81-89.

Kumpulainen, K., Räsänen, E., \& Henttonen, I. (1999). Children involved in bullying: psychological disturbance and the persistence of the involvement. Child Abuse \& Neglect, 23(12), 1253-1262.

Kumpulainen, K., Räsänen, E., Henttonen, I., Almqvist, F., Kresanov, K., Linna, S. L., et al. (1998). Bullying and psychiatric symptoms among elementary school-age children. Child Abuse \& Neglect, $22(7), 705-717$.

Kumpulainen, K., Rasanen, E., \& Puura, K. (2001). Psychiatric disorders and the use of mental health services among children involved in bullying. Aggressive Behavior, 27(2), 102-110.

Langberg, J. M., Epstein, J. N., Becker, S. P., Girio-Herrera, E., \& Vaughn, A. J. (2012). Evaluation of the homework, organization, and planning skills (HOPS) intervention for middle school students with attention deficit hyperactivity disorder as implemented by school mental health providers. School Psychology Review, 41(3), 342-364.

Low, S., \& Espelage, D. (2014). Conduits from community violence exposure to peer aggression and victimization: Contributions of parental monitoring, impulsivity, and deviancy. Journal of Counselling Psychology, 61(2), 221-231. doi:10.1037/aoo35207

Meehan, B. T., Hughes, J. N., \& Cavell, T. A. (2003). Teacher-student relationships as compensatory 
resources for aggressive children. Child Development, 74(4), 1145-1157. doi: 10.1111/1467-8624.00598 Olweus, D. (1998). Bullying at school: What we know and what we can do. Zagreb: Školska knjiga.

Owens, J. S., Goldfine, M. E., Evangelista, N. M., Hoza, B., \& Kaiser, N. M. (2007). A critical review of self-perceptions and the positive illusory bias in children with ADHD. Clinical Child and Family Psychology Review, 10(4), 335-351. doi: 10.1007/s10567-007-0027-3

Perry, D. G., Williard, J. C., \& Perry, L. C. (1990). Peers' perceptions of the consequences that victimized children provide aggressors. Child Development, 61(5), 1310-1325.

Rief, S. (1998). The ADD/ADHD Checklist: An Easy Reference for Parents \& Teachers. Paramus, NJ: Prentice Hall.

Rucklidge, J. J. (2006). Gender differences in neuropsychological functioning of New Zealand adolescents with and without attention deficit hyperactivity disorder. International Journal of Disability, Development and Education, 53(1), 47-66.

Salmivalli, C. (2010). Bullying and the peer group: A review. Aggression and Violent Behavior, 15(2), $112-120$.

Salmivalli, C., Karhunen, J., \& Lagerspetz, K. M. J. (1996). How do the victims respond to bullying? Aggressive Behavior, 22(2), 99-109.

Salmivalli, C., \& Nieminen, E. (2002). Proactive and reactive aggression among school bullies, victims, and bully-victims. Aggressive Behavior, 28(1), 30-44.

Salmivalli, C., \& Peets, K. (2009). Bullies, victims, and bully-victim relationships in middle childhood and early adolescence. In K. H. Rubin, W. M. Bukowski, \& B. Laursen (Eds.), Handbook of peer interactions, relationships, and groups (pp. 322-340). New York, NY \& London, UK: The Guilford Press.

Sciutto, M. J., Nolfi, C. J., \& Bluhm, C. (2004). Effects of child gender and symptom type on referrals for ADHD by elementary school teachers. Journal of Emotional and Behavioral Disorders, 12(4), 247-253. Strom, I. F., Thoresen, S., Wentzel-Larsen, T., \& Dyb, G. (2013). Violence, bullying and academic achievement: A study of 15-year-old adolescents and their school environment. Child Abuse \& Neglect, 37(4), 243-251. doi: 10.1016/j.chiabu.2012.10.010

Swearer, S. M. (2011). Risk factors for and outcomes of bullying and victimization. Educational Psychology Papers and Publications, paper 132. Retrieved from http://digitalcommons.unl.edu/ edpsychpapers $/ 132$

Swearer, S. M., Espelage, D. L., Vaillancourt, T., \& Hymel, S. (2010). What can be done about school bullying? Linking research to educational practice. Educational Researcher, 39(1), 38-47. doi: 10.3102/0013189X09357622

Šimić, N. (2004). Contribution to research the incidence of bullying in school. Unpublished Graduate Thesis. Zagreb: University of Zagreb Faculty of Humanities and Social Sciences. Retrieved from http:// darhiv.ffzg.hr/110/1/Natalija\%C5\%Aoimi\%C4\%87.pdf

Taylor, L. A., Saylor, C., Twyan, K., \& Macias, M. (2010). Adding insult to injury: Bullying experiences of youth with attention deficit hyperactivity disorder. Children's Health Care, 39(1), 59-72.

Timmermanis, V., \& Wiener, J. (2005). Social correlates of bullying in adolescents with attention- 
deficit/hyperactivity disorder. Canadian Journal of School Psychology, 26(4), 301-318. doi: $10.1177 / 0829573511423212$

Unnever, J. D., \& Cornell, D. G. (2003). Bullying, self-control, and ADHD. Journal of Interpersonal Violence, $18(2)$, 129-147. doi: 10.1177/0886260502238731

Wåhlstedt, C., Thorell, L. B., \& Bohlin, G. (2008). ADHD symptoms and executive function impairment: early predictors of later behavioral problems. Developmental Neuropsychology, 33(2), 160-178. doi: 10.1080/87565640701884253

Wang, C., Berry, B., \& Swearer, S. M. (2013). The critical role of school climate in effective bullying prevention. Theory Into Practice, 52(4), 296-302. doi: 10.1080/00405841.2013.829735

Wan Salwina, W. I., Nik Ruzyanei, N. J., Tuti Iryani, M. D., Shamsul, A. S., Aniza, I., \& Zasmani, S. (2010). The association between the attention deficit hyperactivity disorder (ADHD) symptoms and bully/victim problem among Malaysian sixth-graders. ASEAN Journal of Psychiatry, 11(1), 79-86.

Wiener, J., \& Mak, M. (2009). Peer victimization in children with attention-deficit/hyperactivity disorder. Psychology in the School, 46(2), 116-131. doi: 10.1002/pits.20358

Woods, S., \& Wolke, D. (2004). Direct and relational bullying among primary school children and academic achievement. Journal of School Psychology, 42(2), 135-155. doi:10.1016/j.jsp.2003.12.002

\section{Biographical note}

ANAMARIJA ŽIc RALIĆ, PhD, is associate professor at the Faculty of Education and Rehabilitation Sciences, University of Zagreb, Croatia, where she teaches at undergraduate, graduate, postgraduate and doctoral studies. She is guest professor at University of Ljubljana, Slovenia and University of Mostar, Bosnia and Hercegovina. The focus of her scientific and professional interest is social inclusion of children with disabilities, and in this context, social-emotional competences, peer relations and bullying experience of pupils with disabilities.

Daniela Cvitković, PhD, is assistant professor at the Faculty of Education and Rehabilitation Sciences, University of Zagreb. She teaches the course Yoga for children with ADHD at undergraduate study Rehabilitation and the courses Development of children with learning disabilities and Cognitive strategies, at the graduate study Inclusive education and rehabilitation. The area of scientific and professional interest is the inclusion of children and young people with learning disabilities and ADHD. Regarding these topics, she published and presented several scientific publications and participated in several scientific projects. 
SnJežana Sekušak-Galešev, $\mathrm{PhD}$, is psychologist, associate professor at the Faculty of Education and Rehabilitation Sciences, University of Zagreb. She teaches at undergraduate and graduate level at the Faculty of Education and Rehabilitation Sciences at the University of Zagreb 5 courses: Development of Persons with Intellectual Disabilities, Mental health of Persons with Intellectual Disabilities, Play in Rehabilitation, Play Therapy, ADHD, and gives lectures at other universities in Slovenia and Bosnia and Herzegovina as guest professor. The focus of her research work is the bio-psycho-social characteristics of children with developmental difficulties, adolescents and adults with disabilities (especially with intellectual disabilities, ADHD, selective mutism, emotional disabilities, mental health problems), psych diagnostic procedures for vulnerable groups, forms of support - rehabilitation and play therapy, social inclusion and inclusion into regular education and training systems (kindergartens, primary and secondary schools, higher education). 